\title{
Children's Activities on Peace-building Processes in Post Conflict Kenya
}

\author{
Florence Kemuma Maranga $^{1 *} \quad$ Salome Aleso Wangamati $^{2} \quad$ Hellen Inyega $^{3}$ \\ 1.Phd strudent: Department of Peace and Conflict Studies, Kisii University \\ 2. Department of Political Science and Peace studies, Kisii University \\ 3. Department of Communication and Technology, University of Nairobi
}

\begin{abstract}
This study sought to establish the role of children in peacebuilding in Post-conflict Kenya. The research explored children intercommunal peacebuilding activities in Kenya with special emphasis on the Abagusii and Maasai communities of southern Kenya. The research was informed by the New Sociology of Childhood by James and Prout's (1997). The study adopted a mixed research approach with a multiple case study design. The research was carried out along the border of Transmara and Gucha/Kenyenya sub-counties of Narok and Gusii counties respectively. The Transmara and Gucha/ Kenyenya border was purposively selected based on the frequent intercommunal conflict between the Maasai and Abagusii communities in the area. Six public primary schools, three from Narok and three from Kisii counties, respectively, were purposively selected for the study because they were adversely affected by the conflict between the two communities. 435 Class Seven and Class Eight pupils from the six sampled schools were purposively sampled to take part in the study. Twenty three teachers, six head teachers and six key informants, four county education officers and two chiefs were also purposively selected to participate in the study. The tools of data collection included interviews, focus group discussions and observation for qualitative data while quantitative data were collected through semi-structured questionnaires. Secondary data were gathered through document analysis of Nation Newspaper articles and National Music and Drama Festival videos. The research findings demonstrated that Kenyan children engage in a range of peacebuilding activities within their local contexts and at the national level. The activities include, inter-communal games and sports, music and dance, poems and drama, debates,visiting each other's homes, sharing schools, taking part in inter-communal educational and environmental activities and inter-communal exchange programmes enhance inter-communal peace in Kenya. The study concluded that children have the potential to participate in peacebuilding processes in Kenya. The study recommends that government and other peace stakeholders, including local and international peace NGOs ought to come up with and fund more initiatives to enhance children participation in the country's peacebuilding processes at local and national levels. Such initiatives should aim to scale up children voices and space from the confines of music and drama festivals to more strategic fora, such as children's assembly, so as to inform policy.
\end{abstract}

Keywords: Children, Peace building Activities,Conflict and Peace Building

DOI: $10.7176 / \mathrm{DCS} / 9-8-06$

Publication date: August 31st 2019

\section{Introduction}

Currently, 357 million children ( 1 out of 6 children) round the globe live in areas affected by armed conflicts (Save the Children, 2018). In the aftermath of the cold war, civilians including children have increasingly become targets and casualities of armed conflicts (Action on Armed Violence, 2018). Armed conflicts disproportionately affect children who not only suffer the collateral damage of the crossfire but are direct targets as indicated by the United Nations Children Fund (2017) and (Machel, 1996 \& UNICEF, 2002).

Nevertheless, as noted by the UN Resolution 1325 (2000), children seldom participate in peace-building processes. Furthermore, children's impact on reforms in the security sector and their unique contributions to enhancing security and peace-building have largely been ignored because they are not considered actors in matters of the security policy (Nosworthy, 2010).

Studies have shown that children contribute to building intercommuinal peace through advocacy as demonstrated in Bosnia-Herzegovina Guatemala and Uganda where children variously agitated for their rights (Feinstein and O'Kane, 2008). Further, children use sports, arts,drama and music as tools for enhancing intercommunal peace at school community and national levels ((Krasniqi, 2014,Orsborne, 2015, Wood 2015, Roam ,2015, Pruitt, 2016). Sports bring together children from different communities, boosting peace among them (Krasniqi, 2014). Albanian and Serbian children in Kosovo enhanced intercommunal cohesion between them through the Open Fun Football Schools (OFFS) which brought them together to play football(Krasniqi, 2014).

In essence, arts broaden people's perspectives, fostering understanding, empathy and inclusion among different communities (Wood, 2015).

According to Malchiodi (2011), through Art therapy the feeling of well -being and healing of affected individuals is increseased through non-verbal communication, exploration of feelings, self-discovery and catharsis. 
Through arts, victims of violent conflict get an avenue to express and give meaning to their narratives, causing healing to the traumatized victims and restoring inter-communal relationships (Wood, 2015). For instance, listening to songs sung in other people's language, remind people of their common humanity, enhancing harmong among them (Roam, 2015).

Children use drama to appael to leaders and other members of the communities to shun conflict and enhance peace (Kamatsiko, 2005). Pruitt (2016) postulates that drama provides a medium through which young people build peace by engaging in reflexive practices and sharing across cultures. As a result they able to reconceptualize citizenry, multiculturalism and belonging (Pruitt, 2016).

Teaching peace education in schools nurtures a culture of peace in children and enhances their conflictresolution abilities (Abdalla (2012; Berents, 2014; Lauritzen, 2013 \& Morningstar 2015,). Berents (2014), points out that schools provide students with the opportunity to learn alternative ways of resolving conflicts. Further, Peace clubs run in schools impart children with peaceful conflict-resolution skills and values that promote peace at school, home and community levels (Gulliksen, 2015 \& Oseremen, 2014) Slade's (2013) adds that peace education plays a pivotal role in transforming deeply embedded conflict.

Vaughan, Gack, Solorazano, \& Ray, (2003) assert that children learn and retain conservation principles in school environments and transfer them to their homes and communities parents thus enhancing intercommunal peace. Zinc and Eybers (2013) argue that child build intercommunal peace by through joint environmental activities. Children from different communities come together to plant and maintain trees, enhancing relationships and cooperation among them (Zinc \& Eybers,2013).

\section{Materials and Methods}

The study was carried out in Gucha and Transmara sub-counties of Kisii and Narok counties which have been experiencing ongoing conflict since 1997 between the Abagusii and Masaai communities (CRECO, 2012). The study invrestigated the role of children in building peace among the Abagusii and Masaai communities of Kisii and Narok counties respectively.

The study adopted a descriptive mixed method research approach, with multiple case study and content analysis designs. The target population of this study were Standard Seven and Stanadrd Eght pupils aged between 12 and 17 years, parents, teachers, headteachers, local chiefs, and county education officers.

Purposive sampling was used to select six out of the 21 schools situated along the border of Transmara and Gucha/Kenyenya sub county in Narok and Kisii counties that were most adversely affected by the on going violent in the area(CRECO, 2012; Ogega, 2014). Stratified sampling was used to divide children participants into separate groups according to gender. Stratified proportionate sampling was also used to select 435 Standard Seven and Eight pupils and purposive sampling to select twenty three teachers and six head teachers from the six sampled schools, six key informants. Lastly, 15 parents were conveniently sampled to participate in Focus Group Discussions (FGDs).

Qualitative and quantitative methods were employed to collect data from children, teachers, headteachers, education officers and area chiefs. Data were collected using questionniare, Focus Group Discussion guide and individual guide. Qualitative data were analyzed using thematic and content analysis while quantitative data were analyzed by the Statistical Package for Social Sciences (Bryman, 2012 \& Neuman, 2011). Participants informed consent was sought prior to the study and research ethics observed during the study (Willis, 2007 \& Yin, 2016). Further, Permission was sought from parents of participating children (Cohen et al. 2000).

\section{Study Findings}

Findings indicated that childfren engaged in games and sports, music and drama, art, poems, debates, and church crusades, church workshops and seminars in peace-building. They also engaed in joint activities such as visiting each other's homes, sharing schools, taking part in inter-communal education visits, joint environmental activities, joint end-term and mock exams and inter communal exchange programmes to learn each other's culture, including singing in each other's language.

In these activities, messages of peace and cohesion were emphasized to demystify the hatred that existed among the two communities. The activities were undertaken during annual national music and drama festivals and athletics competitions stipulated in the Ministry of Education calender of events.

This was exemplified through the following sentiments :

Paul, a Standard Seven pupil at school 5.

Every year we move from our school to compete with schools from other areas. Many times we and both schools from Maasai and Gusii schools come there. One time I went for sports in Kilgoris and mingled with two Gusii girls. After that they became my friends. Since then we have been friends. On weekends or during holidays I go to visit them in their homes. They also come to my home. At times they stay for two days, three days or even one week. Our parents now know one another and they are friends 
now also. (FGD held on 15/6/2017 in School 5, Transmara County)

Transmara and Kenyenya sub-counties set and administer examinations to learners from both counties. Teachers come together to set and moderate the examinations. After the examinations are done, they are exchanged and marked by teachers of the other sub -county. This has made children from the two subcounties to interact and prepare for the examinations together. They also borrow each other's revision books and go to each other's homes to revise together (A teacher participant at a FGD held on $12^{\text {th }}$ June, 2018 at School 1).

The Young Nation pullout of the Sunday Nation Newspaper reported that "voices of hope had replaced wails of hunger and despair" in the expansive Dandora and Korogocho slums of Nairobi (Muchiri, 2008). This explained how children from different communities residing in the two slums had joined the Jirani Children's Choir (J.C.C) and used songs to urge area members to live peacefully with one another (Muchiri, 2008). Moreover, the sheer fact of being members of the choir made the children to view and treat one another as family, a fact that went a long way to boost peace among local residents (Muchiri, 2008).

Content analysis of sampled songs performed during the $91^{\text {st }}$ Kenya National Music Festivals held between $10^{\text {th }}$ July and 22 ${ }^{\text {nd }}$ August, 2017 at Masinde Muliro University of Science and Technology (MMUST), Kakamega County, under the theme: "Enhancing National Unity, Cohesion and Integrity through Kenya Music Festival" also revealed that children send peace- building messages through music. During the music festivals, children sang songs that urged different communities in Kenya to embrace national unity, cohesion and integrity.

Abagusii and Maasai children participate in joint religious activities which enhance respect, appreciation and peace among them. Children reported that they participated in joint church activities such as path finder, crusades, rallies and camps where they were given spiritual teachings and life skills that emphasise on peaceful co-existence and respect for humanity. Moreover, during camp meetings, children stay away from their homes in camp places, together with children from other communities. Thus they are able to interact and share resources with each other, enhancing inter-communal understanding and appreciation. Children agreed that church teachings condemn fighting, killing, cattle raiding and destruction of property.

During a pupils' FGD at School 4 on $15^{\text {th }}$ June 2017, Charles, a Class Seven boy, invoked the Bible saying, 'The Bible teaches us to love our neighbors as we love ourselves because God has commanded us to do so.' The children further revealed that they shared religious values with their parents and siblings, making them to appreciate their shared ancestry with their neighbours.

this, children were required to indicate on a 5-point Likert Scale the extent to which the statements applied to their communities. The results are presented in table below

\section{Children's Responses on Children's Peace Building Activities}

\begin{tabular}{|l|l|l|l|l|l|l|}
\hline Children activities & $\mathbf{N}$ & Mean & $\begin{array}{l}\text { Std. } \\
\text { Deviation }\end{array}$ & CV\% & T & $\begin{array}{l}\text { Sig. } \\
\text { tailed) }\end{array}$ \\
\hline Children use colours to communicate conflict & 299 & 3.7 & 1.6 & 44 & 39 & 0.000 \\
\hline $\begin{array}{l}\text { Children use objects such as spears, bows and } \\
\text { arrows to symbolize war and conflict }\end{array}$ & 313 & 2.3 & 1.6 & 70 & 25 & 0.000 \\
\hline $\begin{array}{l}\text { Children use colours such as white and green to } \\
\text { communicate messages of peace to members of } \\
\text { different communities in this area }\end{array}$ & 314 & 3.2 & 1.7 & 53 & 34 & 0.000 \\
\hline $\begin{array}{l}\text { Children's drawings such as doves, green branches } \\
\text { and people shaking hands signify peaceful living } \\
\text { between members of my community and members } \\
\text { of other communities }\end{array}$ & 312 & 2.5 & 2.3 & 93 & 19 & 0.000 \\
\hline $\begin{array}{l}\text { Children use objects such as gourds and body } \\
\text { ornaments to communicate peace to members of } \\
\text { other communities }\end{array}$ & 315 & 3.7 & 3.3 & 91 & 20 & 0.000 \\
\hline $\begin{array}{l}\text { Children's use of objects that symbolizes peace } \\
\text { have increased intergration between members of } \\
\text { my community and those of other communities in } \\
\text { this area }\end{array}$ & 312 & 2.7 & 2.0 & 74 & 24 & 0.000 \\
\hline $\begin{array}{l}\text { Children participate in inter-communal games and } \\
\text { sports to enhance peace and cohesion between } \\
\text { neighbouring communities. }\end{array}$ & 311 & 2.2 & 1.6 & 7.4 & 61 & 29 \\
\hline $\begin{array}{l}\text { Children's participation in inter-communal games } \\
\text { and sports has led to increased cohesion among } \\
\text { different communities in my area }\end{array}$ & 311 & 2.4 & 0.000 \\
\hline
\end{tabular}




\begin{tabular}{|l|l|l|l|l|l|l|}
\hline Children activities & $\mathbf{N}$ & Mean & $\begin{array}{l}\text { Std. } \\
\text { Deviation }\end{array}$ & CV\% & T & $\begin{array}{l}\text { Sig. } \\
\text { tailed) }\end{array}$ \\
\hline $\begin{array}{l}\text { Inter-communal games and sports have led to } \\
\text { reduced discrimination among children of our } \\
\text { community and those of neighbouring } \\
\text { communities. }\end{array}$ & 312 & 2.4 & 1.4 & 57 & 31 & 0.000 \\
\hline $\begin{array}{l}\text { Children's participation in inter-communal games } \\
\text { and sports has enhanced cohesion between my } \\
\text { community and our neighbouring communities }\end{array}$ & 311 & 2.5 & 3.7 & 150 & 12 & 0.000 \\
\hline $\begin{array}{l}\text { Through participation in inter-communal games } \\
\text { and sports, children in my community are able to } \\
\text { reconcile with children from other commuities in } \\
\text { my area }\end{array}$ & 313 & 2.2 & 1.4 & 67 & 26 & 0.000 \\
\hline $\begin{array}{l}\text { Participation in school debates has made me to } \\
\text { appreciate members of other communities }\end{array}$ & 314 & 1.97 & 1.33 & 68 & 26 & 0.000 \\
\hline $\begin{array}{l}\text { Participation in school debates has made me to } \\
\text { value peaceful cohabitation with other members of } \\
\text { other communities }\end{array}$ & 315 & 2.70 & 5.24 & 194 & 9 & 0.000 \\
\hline $\begin{array}{l}\text { Music and dance in my community send messages } \\
\text { that enhance inter-communal peace }\end{array}$ & 313 & 2.51 & 3.78 & 151 & 12 & 0.000 \\
\hline $\begin{array}{l}\text { Drawings that carry peace messages have enabled } \\
\text { me to respect and live peacefully with members } \\
\text { from other communities }\end{array}$ & 313 & 2.32 & 1.82 & 78 & 23 & 0.000 \\
\hline $\begin{array}{l}\text { I have participated in tree planting activities in my } \\
\text { community to enhance peace }\end{array}$ & 314 & 2.75 & 1.69 & 62 & 29 & 0.000 \\
\hline Tree planting enhances inter community peace & 299 & 2.59 & 3.95 & 152 & 11 & 0.000 \\
\hline
\end{tabular}

The results in Table above are moderately ranking high with respect to children's activities (with mean scores above 2.5 for most of the children's activities descriptions). Notably, all statements had high $t$-values, yielding statistically significant ( $p$ values of less 0.05 ) results. The aspect 'children activities was dominated by use of colours, objects, school debates, and tree planting activities' which had the highest mean score of greater than 2.5, thus affecting peace building process to a large extent. The statements 'participation in inter-communal games and sports and 'use of spears, bows and arrows' had the lowest mean score of 1.97, 2.2 and 2.3 respectively, implying that children almost disagreed to this statement.

'Use of colours to communicate conflict' had the lowest coefficient of variation (CV) of 44 percent, suggesting that there was a relatively high level of agreement among the respondents that relationships with 'use of colours to communicate conflict and peace to a large extent matter on issues of conflict and peace-building.

Teachers were also asked to provide responses on the effect of children's activities on peace building. The findings are presented in Table below.

Teachers' Responses on Children's Activities in Peace building

\begin{tabular}{|l|l|l|l|l|l|l|}
\hline Children activities & $\mathbf{N}$ & Mean & $\begin{array}{l}\text { Std. } \\
\text { Deviation }\end{array}$ & CV\% & T & $\begin{array}{l}\text { Sig. } \\
\text { tailed) }\end{array}$ \\
\hline $\begin{array}{l}\text { Both boys and girls take part in peace } \\
\text { building process in Kenya }\end{array}$ & 22 & 2.2 & 1.1 & 50 & 9 & 0.00 \\
\hline $\begin{array}{l}\text { Through participation in drama, children } \\
\text { developed tolerance toward children from } \\
\text { other communities }\end{array}$ & 22 & 2.2 & 0.9 & 42 & 11 & 0.00 \\
\hline $\begin{array}{l}\text { School debates teach children to live } \\
\text { peacefully with members of other } \\
\text { communities in this area }\end{array}$ & 23 & 2.0 & 0.9 & 43 & 11 & 0.00 \\
\hline $\begin{array}{l}\text { Children's participation in school debates has } \\
\text { enhanced peaceful cohabitation among } \\
\text { members of different local communities }\end{array}$ & 23 & 2.6 & 0.9 & 35 & 14 & 0.00 \\
\hline $\begin{array}{l}\text { Children's Participation in intercommunal } \\
\text { tree planting activities has enhanced } \\
\text { intergration and peace in this area }\end{array}$ & 23 & 2.7 & 1.2 & 43 & 11 & 0.00 \\
\hline
\end{tabular}

As shown in Table above, teachers' responses show low ranking with respect to children activities (mean scores of above 2.0 for most of the children's activities descriptions). Teachers agreed with pupils that children's 
participation in inter-communal tree planting activities (mean score 2.7 and school debates (mean score 2.6) enhanced peaceful cohabitation among members of different local communities. All statements had high $t$-values, yielding to statistically significant ( $p$ values of less 0.05 ) results. Children participation in inter-communal tree planting activities had the lowest coefficient of variation (CV) of 35 percent, suggesting that there was a relatively high level of agreement among the respondents that 'tree planting activities' to a large extent matter in the enhanced peaceful cohabitation among members of different local communities.

The study also sought responses from the area chiefs and headteachers on children peace- building activities. Their findings are presented in Table below.

Key Informants' Responses on Children's Activities in Peace building

\begin{tabular}{|l|l|l|l|l|l|l|}
\hline Children activities & $\mathbf{N}$ & Mean & $\begin{array}{l}\text { Std. } \\
\text { Deviation }\end{array}$ & CV & T & $\begin{array}{l}\text { Sig. } \\
\text { tailed) }\end{array}$ \\
\hline $\begin{array}{l}\text { Through participation in drama, children have } \\
\text { developed tolerance toward children from other } \\
\text { communities }\end{array}$ & 9 & 1.6 & 0.7 & 47 & 6.4 & 0.00 \\
\hline $\begin{array}{l}\text { School debates teach children to live peacefully with } \\
\text { members of other communities in this area }\end{array}$ & 9 & 1.6 & 0.5 & 34 & 8.9 & 0.00 \\
\hline $\begin{array}{l}\text { Children participation in school debates has } \\
\text { enhanced peaceful cohabitation among members of } \\
\text { different local communities }\end{array}$ & 9 & 1.9 & 1.3 & 67 & 4.5 & 0.002 \\
\hline
\end{tabular}

The responses in Table above from the chiefs and head teachers show low ranking with respect to children's activities (mean scores less than 2.0 for most of the children's activities descriptions). Chiefs and head teachers agreed with pupils that participation in school debates (mean score 1.9) enhanced peaceful cohabitation among members of different local communities. All statements had relatively high $t$-values yielding to statistically significant ( $p$ values of less than 0.05 ) results. Children participation in school debates had the lowest coefficient of variation $(\mathrm{CV})$ of 34 percent, suggesting that there was a relatively high level of agreement among the respondents that relationships with 'school debates' to a large extent matter in the enhancement of peaceful cohabitation among members of different local communities.

The study also sought responses from the education officers on the influence of children activities on peacebuilding, the results of the analysis are shown in Table below.

Education Officers Responses on Children's Activities in Peace building

\begin{tabular}{|l|l|l|l|l|l|l|}
\hline Children activities & $\mathbf{N}$ & Mean & $\begin{array}{l}\text { Std. } \\
\text { Deviation }\end{array}$ & CV\% & T & $\begin{array}{l}\text { Sig. } \\
\text { tailed) }\end{array}$ \\
\hline $\begin{array}{l}\text { Through participation in drama, children have } \\
\text { developed tolerance toward children from other } \\
\text { communities }\end{array}$ & 3 & 1.7 & 0.6 & 34.6 & 5 & 0.0 \\
\hline $\begin{array}{l}\text { Songs and dance have taught children to appreciate } \\
\text { and coexist with members of other communities }\end{array}$ & 3 & 1.3 & 0.6 & 43.3 & 4 & 0.1 \\
\hline $\begin{array}{l}\text { School debates teach children to live peacefully } \\
\text { with members of other communities in this area }\end{array}$ & 3 & 2.0 & 1.0 & 50.0 & 3 & 0.1 \\
\hline $\begin{array}{l}\text { Children participation in school debates has } \\
\text { enhanced peaceful cohabitation among members } \\
\text { of different local communities }\end{array}$ & 3 & 2.0 & 1.0 & 50.0 & 3 & 0.1 \\
\hline
\end{tabular}

The results in Table above from the education officers show low ranking with respect to children's activities (mean scores less than 2.0 for most of the children's activities descriptions). Likewise, education officers agreed that children participation in school debates (mean score 2.0) enhanced peaceful cohabitation among members of different local communities.

\section{Conclusion}

This study established that children's activities contribute to peace-building process (Berents and McEvoy-Levy, 2015; Nosworthy, 2009 \& Oriedo et al. 2018). The findings imply that children are actors in social, economic and political activities which contribute to sustainable peace in the country. Hence there should be a paradigm shift from problematizing children as individuals needing protection to viewing them as active agents with the power and agency to contribute to lasting inter-communal peace in the country (Leonard, 2013; Pontalti, 2010). It is imperative for the Kenyan government and international and local NGOs and other peace stakeholders to incorporate children's views and experiences in the peace-building processes in the country.

\section{Recommendations}

The study recommends that: Local and international NGOs and other peace agencies should engage in ambitious initiatives aimed at scaling up children's voice and space in the peace-building processes in the country. Based on 
the study findings, the study recommends that the government, local and international NGOs should come up with robust programs to sensitize citizenry, children, teachers, local administrators and education officials on the provisions of legal instruments. There is need for more research in children's participation in peacebuilding is required in order to provide in-depth perceptions of children about peace-building process in Kenya. Moreover, the government should commit to funding divergent children peace-building activitiessuch as public speaking and writing competitions at the local and national levels. Lastly, the government and other peace stakeholders in the country should create more local and national forums for children to take part in peace-building activities.

\section{References}

Abdalla, S. (2012). Peace education in post-conflict societies: the case of the Young Peace Ambassador Program in Somalia and Kenya (Doctoral dissertation, University of South Africa).

Action on Armed Violence (2018): "First 11 Months of 2017 sees 42\% Increase in Civilian Deaths from Explosive Weapons Compared to 2016": https://aoav.org.uk/2018/2017-setworst-year-civilian-fatalities-since-aoavrecords-began/

24Crossborder $\% 20$ water $\% 20$ cooperation $\% 20$ and $\% 20$ peacebuilding $\% 20$ in $\% 20$ the $\% 20$ Middle $\% 20$ East_ 201 1_ENG. pdf.

Banda, K. (2008, June 8). Saving the Environment.Sunday Nation Newspaper, pp.3

Bryman, A. (2012). Social Research Methods( 4th Edition). Oxford, UK: Oxford University Press.

Machel, G. (1996). Impact of armed conflict on children. UN.

Malchiodi, C. A. (2011). Handbook of art therapy. New York, NY: Guilford Press.

Morningstar, M. T. (2015). The Effects of a Peace Curriculum on Reducing and Resolving Conflicts among Children Ages 3-6 Years.

Muchina. M. (2008, June 15). Young Environmentalists Crowned. Sunday Nation Newspaper, pp.3.

Muchina, M. (2008, August 31). Our Flag and the National Anthem, Sunday Nation Newspaper, pp. 4

Muchina, M. (2008, August 31). Our Flag and the National Anthem, Sunday Nation Newspaper, pp. 4

Muchiri, J.(2008, APRIL 13). What Leaders should do to Maintian Peace. Sunday Nation Newspaper, pp.3

Muchiri, J. (2008, august 17). Voices of Hope. Sunday Nation Newspaper, pp. 1

Munyi, O. (2008, September 21). British Airways Young Ambasssador. Sunday Nation, pp.3.

Neuman, L. W. (2011). Social Research Methods: Qualitative Approaches (Seventh Edition). Boston, Pearson.

Nosworthy, D. (2009). Seen, but not Heard: Placing Children and Youth on the Governance Agenda: Zurich: Lit Verlag GmbH\& Co.

Nosworthy, D. (2010). “Children and Security Sector Reform in Post-Conflict Peace-Building” Innocenti Working Paper No. 2010-9. Florence, UNICEF Innocenti Research Centre.

Ogega, J. C. (2015). Faith, gender and peacebuilding: The roles of women of faith in peacebuilding in the Conflict between the Gusii and Maasai of south-western Kenya (Doctoral dissertation, University of Bradford)

Oseremen, Irene (2015). Building Infrastructure for Peace: An Action Research Project in Nigeria.Phd Thesis. Durban University of Technology

Roam, S. (2015), "Take it to the Bridge: The Arts of Interfaith Peacebuilding". Doctor of Ministry. Paper 97.http://digitalcommons.georgefox.edu/dmin/97

Save the Children( 2018).The War on Children:Time to End Grave Violence Against Children in Conflict.https://www.savethechildren.org/content/dam/usa/reports/advocacy/war-on-children-report-us.PDF Acessed on 23rd April 2018

Slade, S. (2013). Peace Education for Children in Post-Conflict Societies as Part of a Conflict Transformative Approach: Theory in Practice?

UNICEF (2002). Children Affected by Armed Conflict: UNICEF Actions

Vaughan, C., Gack, J., Solorazano, H., \& Ray, R. (2003). The effect of environmental education on schoolchildren, their parents, and community members: A study of intergenerational and intercommunity learning. The Journal of Environmental Education, 34(3), 12-21.

Zinck, E., \& Eyber, C. (2013). Environmental Education to Promote Peace and Cooperation: A Case Study of Tree Nurseries in Nakuru, Kenya. Children Youth and Environments, 23(1), 198-210.

In Nosworthy D. (Ed.) (Forthcoming 2008) Seen, but not Heard! Placing Children and Youth on the Security Governance Agenda. LIT Verlag. 